症例

\title{
空腸横行結腸瘦を形成した 幽門輪温存膵頭十二指腸切除後吻合部潰瘍の 1 例
}

JA 愛知厚生連豊田厚生病院外科

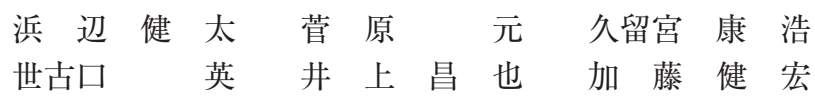

症例は63歳, 男性. 11年前に膵神経内分泌腫瘍に対して幽門輪温存膵頭十二指腸切除 術施行の既往がある。 6 力月前より黒色便を自覚し, 上部消化管内視鏡検査で十二指腸 空腸吻合部に潰瘍を認め, プロトンポンプ阻害薬を内服し経過観察されていた，その後, 黒色便を伴う下痢および粪臭曖気が出現し, 当科を受診した。当科受診時の上部消化管 内視鏡検査では吻合部に横行結腸との瘦孔を認め, 下部消化管造影検査でも吻合部との 交通が確認された。 十二指腸空腸横行結腸瘻と診断し, 広範囲胃切除を併施する十二指 腸空腸吻合部切除・横行結腸楔状切除を行い, 残胃と空腸はRoux-en Y 法で再建し, 横行結腸楔状切除部を縫合閉鎖した. 病理組織学的検査で吻合部潰瘍を認めたものの, 腫瘍性病変は認めなかった. 術後12力月現在, 潰瘍性病変の再発を認めていない. 膵頭 十二指腸切除後の吻合部潰瘍を原因とする十二指腸空腸横行結腸瘦の報告は稀である.

索引用語：幽門輪温存膵頭十二指腸切除術, 空腸横行結腸瘻, 吻合部潰瘍

\section{緒言}

膵頭十二指腸切除 (pancreaticoduodenectomy；PD) 術後の晚期合併症の一つとして吻合部潰瘍が挙げられ るが，出血や穿孔を生じ重篤な合併症となりうる病態 である．今回われわれは，膵神経内分泌細胞腫瘍に対 し幽門輪温存膵頭十二指腸切除 (Pylorus-preserving $\mathrm{PD} ； \mathrm{PpPD})$ 術後，11年を経て発症した吻合部潰瘍に よる十二指腸空腸横行結腸瘦を経験したので，文献的 考察を加えて報告する.

\section{症例}

患者：63歳, 男性.

主訴：黒色便を伴う下㾥および翼臭曖気.

既往歴：11年前, 膵神経内分泌腫瘍に対しPpPDを 施行, Child変法再建 (当院).

家族歴, 生活歴 : 特記事項なし.

現病歴：6力月前, 腹痛と黒色便を主訴に近医を受 診し, 上部消化管内視鏡検查で十二指腸空腸吻合部に白 苔付着を伴う A2 stageの潰瘍を指摘され（Fig. 1a）,

2021年 1 月 6 日受付 2021 年 2 月 26 日採用

〈所属施設住所〉

干470-0396 豊田市浄水町伊保原500- 1
プロトンポンプ阻害薬（PPI）が内服開始された。服 薬を継続したが，黒色便を伴う下痢および翼臭曖気が 出現し, 症状増悪したために当科へ紹介初診となった.

現症 : 身長 $169 \mathrm{~cm}$, 体重 $50 \mathrm{~kg}$. 腹部は平坦・軟で, 圧痛を認めなかった。

血液検査所見 : $\mathrm{Hb} 12.2 \mathrm{~g} / \mathrm{dl}$, Hct $37.5 \%$ と軽度の貧 血を認めた。

当科受診時上部消化管内視鏡検査 : 吻合部の空腸側 に, 6 力月前の検査では認めなかった瘦孔を認め, 結 腸との交通が疑われた（Fig. 1b).

下部消化管内視鏡検査 : 横行結腸に瘦孔を認め, 空 腸との交通が疑われた（Fig. 2).

注腸造影検査：横行結腸に造影剤を注入すると, 胃・ 空腸が造影された（Fig. 3).

上記検査より，十二指腸空腸吻合部潰瘍による十二 指腸空腸横行結腸瘦と診断し, 手術を施行した

手術所見：結腸前経路で十二指腸空腸吻合が施行さ れており，炎症のために横行結腸と十二指腸空腸吻合 部が一塊となっていた，瘦孔を含めて広範囲胃切除を 併施する十二指腸空腸吻合部切除・横行結腸楔状切除 を施行した（Fig. 4a）。残胃と空腸はRoux-en Y 法で 再建し, 横行結腸楔状切除部は縫合閉鎖した（Fig. 4b). 

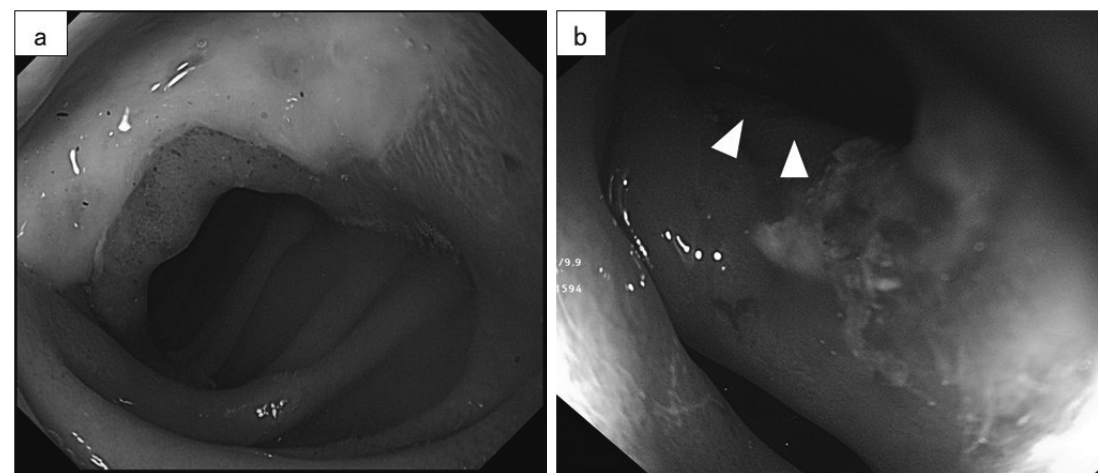

Fig. 1 上部消化管内視鏡検査画像：a）当科受診 6 力月前のもの.十二指腸空腸吻合部 に白苔付着を伴う A 2 stageの潰瘍を認めた。 b ) 当科受診時のもの. 吻合部の空腸側 に6カ月前の検査では認めなかった瘦孔を認めた (矢頭).

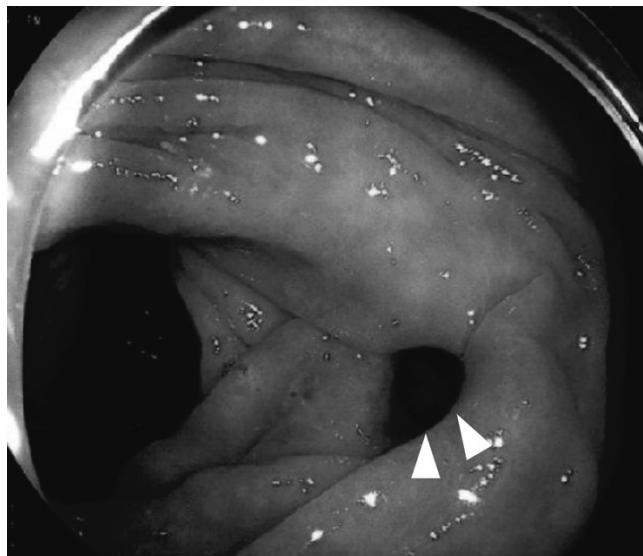

Fig. 2 下部消化管内視鏡検査画像 : 当科受診時のも の. 横行結腸に瘦孔を認めた (矢頭)

切除標本肉眼所見：十二指腸空腸吻合部（矢頭）の 輸出脚側に $5 \mathrm{~mm}$ 大の㾇孔（矢印）を認め, 横行結腸 と交通していた (Fig. 5a)。空腸粘膜のひだが瘦孔に 集中しており，潰瘍形成の所見と考えた。割面像では 吻合部 (矢頭) の空腸側に空腸粘膜の離断（矢印）を 認め, 空腸の背側には横行結腸の粘膜を認めた（Fig. 5b)。吻合部周囲に腫瘍性病変は認めなかった。

病理組織学的所見：ルーペ像では，離断した空腸粘 膜の口側に, 瘻孔の背側から連続する結腸粘膜を認め た. 十二指腸粘膜と結腸粘膜との間には潰瘍を認めた (Fig. 6a).ルーペ像をもとに割面の粘膜像に十二指 腸・空腸・結腸と識別したものを示す (Fig. 6b). 拡 大像において，十二指腸粘膜と結腸粘膜の間には固有 筋層に至る潰瘍を認めた。 不整な固有筋層は空腸の固

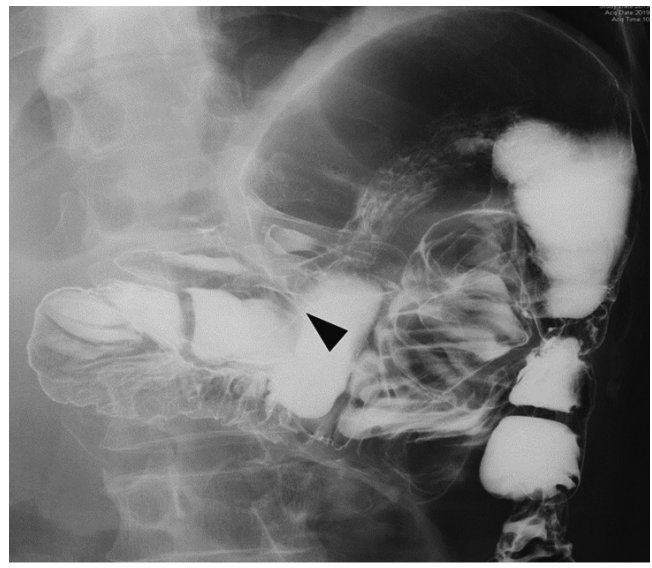

Fig. 3 注腸造影検査：当科受診時のもの. 横行結腸 より胃・空腸が造影された (矢頭).

有筋層と考えられ，同部位が十二指腸空腸吻合部であ ると推測した（Fig. 6c).

術後経過：経過は良好で術後15日目に退院した。術 後12力月の時点で, 下痢および粪臭曖気などの症状は 改善し, 潰瘍性病変の再発を認めていない.

\section{考察}

本症例はPpPD施行後11年経過して, 発症した十二 指腸空腸横行結腸㾇である. 6 力月前に施行した上部 消化管内視鏡検査の所見をもとに推測すると，吻合部 潰瘍が原因となって十二指腸空腸横行結腸瘦という重 篤な合併症を発症したと考えられる.PD施行後の吻 合部潰瘍については, 1948年にOwens ${ }^{1}$ が初めて報告 している. 膵頭十二指腸切除後の吻合部潰瘍の発症頻 度は, 胃切除を伴う古典的PD術後で $0-2.6 \%$, 幽門 

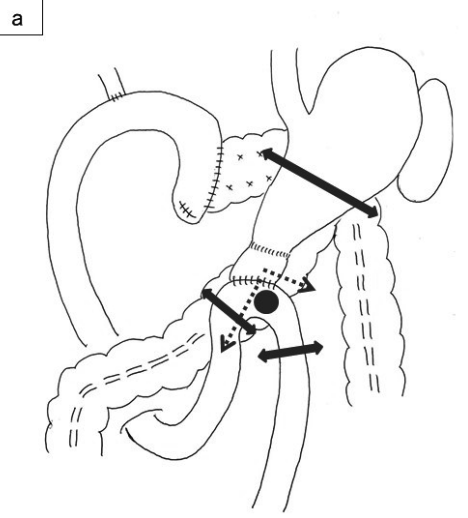

b

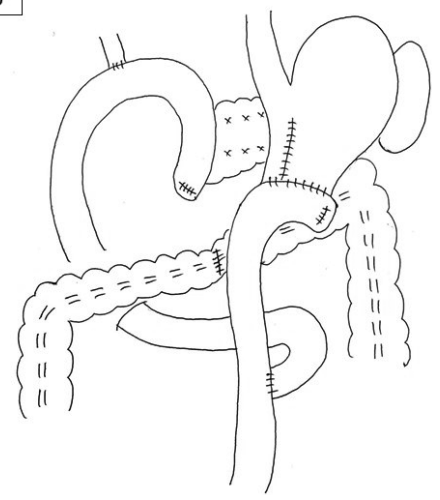

Fig. 4 手術所見シェーマ： a ) 瘦孔（黒丸）を含めて広範囲胃切除を併施する 十二指腸空腸吻合部切除・横行結腸楔状切除を施行した。 b ）切除後, 残胃と 空腸はRoux-en Y 法で再建し，横行結腸楔状切除部は縫合閉鎖した.
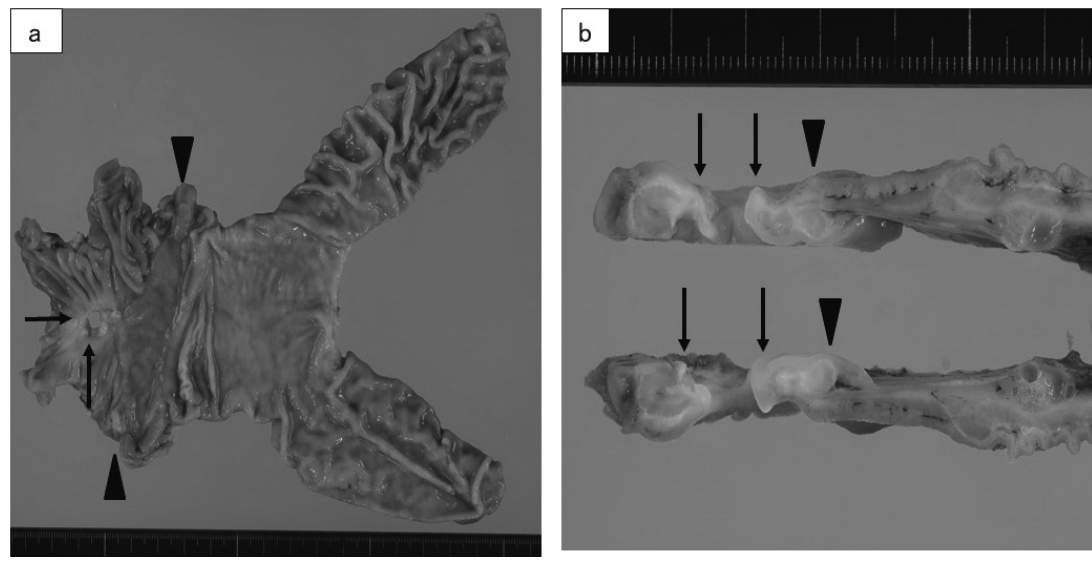

Fig. 5 切除標本肉眼所見：a）吻合部（矢頭）の空腸側と横行結腸に $5 \mathrm{~mm}$ 大の㾇孔（矢 印）を認め, 周囲に潰瘍を認めた. 腫瘍性病変は認めなかった. b ) 割面像. 吻合部（矢 頭）の空腸側に空腸粘膜の離断を認め (矢印), 空腸の背側には横行結腸の粘膜を認めた.

輪を温存する PpPD術後で2.0-14.3\%と報告されてい $ろ^{2) \sim 4)}$. PPIの使用が一般的になった2015年報告のメ タアナリシスでも, 術後吻合部潰瘍の発症頻度は 2.5 \%と報告されており ${ }^{5)}$ ，膵頭十二指腸切除後の晚期合 併症としては糖尿病や胆管炎のほかに，吻合部潰瘍の 発症についても十分に留意する必要がある.

胃切除後の吻合部潰瘍についてはBillroth II 法再建 で多いとされるが，これは輸入脚からの胆汁流入によ り胃酸中和機構に障害が起こり, 酸度の高い胃液に吻 合部付近の空腸が暴露され潰瘍ができやすいためであ $る^{6)}$. 脺頭十二指腸切除後の吻合部潰瘍の原因も同様 に，胃酸が原因であることが多いと考えられてい
る ${ }^{7)}$. 胃酸分泌は, ガストリン性酸分泌と迷走神経 性酸分泌に大別できる。広範囲胃切除を伴うPDでは ガストリン細胞の存在する胃前庭部と十二指腸を切除 するため，ガストリン性酸分泌は少ないと考えられ， 胃が温存されるPpPDではガストリン性酸分泌が多い と考えられる．本症例は全胃を温存するPpPDを施行 しChild変法再建されているので, 胃切除後の Billroth II 法再建同様に，吻合部潰瘍の原因は酸であると考え ている6)9).

吻合部潰瘍に対する治療としてはPPIやヒスタミン $\mathrm{H}_{2}$ 受容体拮抗薬 $\left(\mathrm{H}_{2} \mathrm{RA}\right)$ などの酸分泌抑制薬の投与 が主流であり，大部分は保存的治療で改善する。本症 


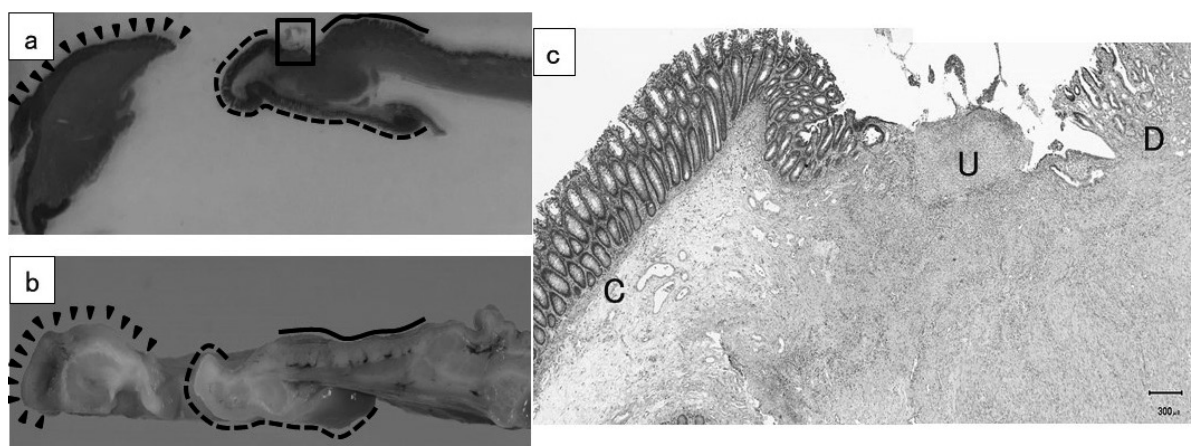

Fig. 6 病理組織学的所見：a）H.E.染色 (ルーペ像)。瘦孔の口側に十二指腸粘膜（実線），肛門 側には空腸粘膜（矢頭）を認め, 十二指腸空腸吻合部㾇孔の背側には部分切除した横行結腸を 認めた (点線)。十二指腸粘膜と結腸粘膜との間には潰痬を認めた（枠）。 b ）肉眼割面像に 十二指腸粘膜 (実線), 空腸粘膜 (矢頭), 結腸粘膜 (点線), を識別したもの. c ) H.E.染色 ( $\times$ 40倍). 十二指腸粘膜（D）と結腸粘膜（C）の間には固有筋層に至る潰瘍（U）を認めた. 潰 瘍の背側は筋層が不整であり, 十二指腸空腸吻合部であると考えられた.

例は全胃を温存したPpPD術後症例であり，吻合部潰 瘍の原因としてガストリン性酸分泌を第一に考え，胃 酸分泌を抑制すべくPPIによる治療を開始した，服薬 コンプライアンスに問題は無かったが，吻合部潰瘍は 悪化し結腸との瘦孔を形成したことから，本症例の吻 合部潰瘍の原因としては，ガストリン性酸分泌ではな く, 迷走神経性酸分泌が関与していた可能性が高いと 推測される.

篠田ら ${ }^{10)}$ はPD術後の吻合部潰瘍に対し, PPIおよ び $\mathrm{H}_{2} \mathrm{RA}$ を投与したにも拘わらず，難治性であった症 例を報告している。治療法として吻合部切除もしくは 迷走神経切離を検討したうえで, PDに加え直腸切断 術の既往があったことから，手術侵襲を考虑して胸腔 鏡下全幹迷走神経切離を施行し, 難治性吻合部潰瘍が 改善し良好な結果が得られたと報告している。吻合部 潰瘍に対して薬物による保存的治療を施行する際は, 治療効果を確認するために定期的に内視鏡検查を施行 し, 治療効果が不十分であった場合は, 吻合部潰瘍の 原因として迷走神経による酸分泌も念頭に置いて治療 法を再考する必要がある.

1995年から2020年までの期間に「膵頭十二指腸切除 術」「吻合部潰瘍」「㾇孔」をキーワードに医学中央雑 誌（会議録を除く）で検索した範囲では，膵頭十二指 腸切除後の吻合部潰瘍による十二指腸空腸横行結腸瘦 の報告例は存在せず，本症例が初の報告となる，同様 の発症機序と考えられる膵頭十二指腸切除後の吻合部 潰瘍穿孔例に関しては報告が散見される ${ }^{1112)}$. 治療法
は, 穿孔部閉鎖 +大網被覆などの低侵襲な術式や保存 的治療などが選択され良好な経過が報告されている. 既に膵頭十二指腸切除が施行されている症例に対する 再手術であり, 可能であれば低侵襲な術式を選択すべ きであろう。本症例のように, 十二指腸空腸吻合部と 横行結腸の間に瘦孔を形成すると, 下痢や糞臭曖気な どの臨床症状を解消するためには瘦孔切除が必要とな る. 本症例に打いては, PPI投与にも拘わらず，吻合 部潰瘍が改善しなかったことから広範囲胃切除を伴う 術式を選択した。

膵頭十二指腸切除後に吻合部潰瘍を発症した場合 は, 薬物治療による保存的治療を選択することが多い が, 吻合部潰瘍穿孔や吻合部と結腸との間に瘦孔を形 成する可能性も念頭に置き, 定期的に内視鏡検査を施 行することが推奨される，難治性である場合には，保 存的治療に固執することなく迷走神経切離や吻合部切 除などの治療法も考慮し, 吻合部と結腸の瘦孔形成を 未然に防ぐことが重要である.

\section{結語}

PpPD施行後11年経過して発症した吻合部潰瘍によ る十二指腸空腸横行結腸瘦を形成した 1 例を経験した ので, 若干の文献的考察を加えて報告した.

なお，本論文要旨は第53回愛知臨床外科学会 (2020 年 2 月, 名古屋) で発表した。

利益相反：なし 


\section{文献}

1) Owens FM : Problem of peptic ulcer following pancreatectomy. Ann Surg 1948; $128: 15-20$

2) Yamaguchi K, Tanaka M, Chijiiwa K, et al : Early and late complications of pylorus-preserving pancreatoduodenectomy in Japan 1998. J Hepatobiliary Pancreat Surg $1999 ; 6: 303-311$

3) Sakaguchi T, Nakamura S, Suzuki S, et al : Marginal ulceration after pylorus-preserving pancreaticoduodenectomy. J Hepatobiliary Pancreat Surg $2000 ; 7: 193-197$

4）今泉俊秀 : 膵頭十二指腸切除術 - 術後合併症とそ の対策. 日消外会誌 $1996 ; 29: 127-131$

5) Butler JR, Rogers T, Eckart G, et al : Is antisecretory therapy after pancreatoduodenectomy necessary? Metaanalysis and contemporary practices of pancreatic surgeons. J Gastrointest Surg $2015 ; 19: 604-612$

6）加藤 綾, 佐伯博行, 藤澤 順他：吻合部潰痬に よる胃空腸結腸瘦の 1 例. 日外科系連会誌 $2015 ; 40$ : 1096-1100
7）山下裕一，笠原小五郎，宮田道夫他：膵頭十二指 腸切除術後胃空腸吻合部潰瘍一迷切により治癒せ しめた 1 例一. 日臨外会誌 $1983 ; 44: 1307$ 1313

8）山下裕一, 黒肱敏彦, 兵藤 真他：膵頭十二指腸 切除術後の胃酸分泌ならびにガストリン放出につ いての検討. 日消外会誌 $1987 ; 20: 2103-2107$

9) Hedberg J, Hedenstrbm H, Nilsson S, et al : Role of gastric acid in stomal ulcer after gastric bypass. Obes Surg $2005 ; 15: 1375-1378$

10）篠田知太朗, 小村伸朗, 田中知行 : 胸腔鏡下全幹 迷走神経切離で改善した膵頭十二指腸切除術後の 難治性吻合部潰瘍の 1 例. 日臨外会誌 2012 ; $73: 857-862$

11）小川克大, 白石裕大, 丸野正敬他：亜全胃温存膵 頭十二指腸切除後の胃空腸吻合部潰瘍穿孔 5 例の 検討. 癌と化療 $2020 ; 47: 156-158$

12) Shioi I, Yokoyama N, Hirai M, et al : Perforation of anastomotic peptic ulcer following pancreaticoduodenectomy : a report of three cases. BMC Surg $2020 ; 20: 79$

\title{
A CASE OF JEJUNAL TRANSVERSE COLON FISTULA DUE TO ANASTOMIC ULCER AFTER PYLORUS-PRESERVING PANCREATICODUODENECTOMY
}

\author{
Kenta HAMABE, Gen SUGAWARA, Yasuhiro KURUMIYA, \\ Ei SEKOGUCHI, Masaya INOUE and Takehiro KATO \\ Department of Surgery, JA Aichi Kouseiren Toyota Kosei Hospital
}

A 63-year-old man presented to our department because of diarrhea with tarry stool and halitosis. He had undergone pylorus-preserving pancreaticoduodenectomy for a pancreatic neuroendocrine tumor 11 years earlier. Esophagogastroduodenoscopy (EGD) conducted for tarry stool, of which he was aware 6 months before, showed an ulcer at the duodenal-jejunal anastomosis, and he had been administered an oral proton pump inhibitor. EGD taken in our department showed a fistula with the transverse colon at the same site. A Jejunal transverse colon fistula due to anastomotic ulcer was diagnosed and surgery was performed. A duodenal-jejunal anastomosis was performed by the anterior colonic route, which caused a mass due to inflammation. Gastrectomy was performed including the anastomosis forming the fistula and the transverse colon. Histologically, an ulcer was found in the jejunum near the anastomosis, but no neoplastic lesion was found. The postoperative course was favorable, and the patient was discharged on the 15th postoperative day. No recurrence of ulcerative lesions has been observed as of 12 months after the surgery. Gastrointestinal fistula caused by anastomotic ulcer after pancreaticoduodenectomy is rare.

Key words : pylorus-preserving pancreaticoduodenectomy, jejunal transverse colon fistula, anastomotic ulcer 